Received: 23 February 2017

Accepted: 2 May 2017

Published online: 09 June 2017

CIENTIFIC REP

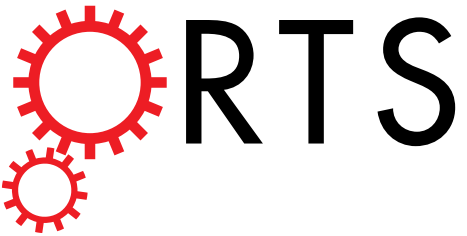

OPEN Unique copper and reduced graphene oxide nanocomposite toward the efficient

\title{
electrochemical reduction of carbon dioxide
}

\section{Nur Hossain, Jiali Wen \& Aicheng Chen}

The electrochemical reduction of $\mathrm{CO}_{2}$ to useful chemicals and fuels has garnered a keen and broad interest. Herein, we report a unique nanocomposite consisting of Cu nanoparticles (NPs) and reduced graphene oxide ( $\mathrm{rGO}$ ) supported on a $\mathrm{Cu}$ substrate with a high catalytic activity for $\mathrm{CO}_{2}$ reduction. The nanocomposite was optimized in terms of the composition of Cu NPs and rGO as well as the overall amount. A gas chromatograph was employed to analyze the gaseous products, whereas a chemical oxygen demand (COD) method was proposed and utilized to quantify the overall liquid products. The optimized nanocomposite could effectively reduce $\mathrm{CO}_{2}$ to $\mathrm{CO}, \mathrm{HCOOH}$ and $\mathrm{CH}_{4}$ with a Faradaic efficiency (FE) of $76.6 \%$ at $-0.4 \mathrm{~V}$ (vs. $\mathrm{RHE}$ ) in a $\mathrm{CO}_{2}$ saturated $\mathrm{NaHCO}_{3}$ solution. The remarkable catalytic activity, high $\mathrm{FE}$, and excellent stability make this $\mathrm{Cu}-\mathrm{rGO}$ nanocomposite promising for the electrochemical reduction of $\mathrm{CO}_{2}$ to value-added products to address the pressing environmental and energy challenges.

Increasing levels of $\mathrm{CO}_{2}$ in the atmosphere have created a highly concerning situation that continues to elevate global average temperatures. There is a growing frequency of reports related to the impacts of global climate change due to increasing greenhouse gas emissions via the continuous combustion of fossil fuels. One of the most notorious of the greenhouse gases is $\mathrm{CO}_{2}$, which is released by both natural and anthropogenic processes. There is a great interest in capture and sequestration of $\mathrm{CO}_{2}$ emissions prior to their release into the ambient atmosphere, or the conversion of this gas to useful products such as fuels ${ }^{1-5}$. Over the last few decades, various electrocatalysts have been explored for the electrochemical reduction of $\mathrm{CO}_{2}$ to valuable fuels ${ }^{6-10}$, and a wide range of gas and liquid products may be formed. Therefore, it is essential to accurately determine both the produced gases and the liquid fuels in order to precisely assess the FE. On one hand, the primary gas products include CO, methane $\left(\mathrm{CH}_{4}\right)$, and ethane, which may be determined using GC and gas chromatography mass spectrometry (GC-MS $)^{11,12}$. On the other hand, potential liquid products include formate, acetate, aldehyde, alcohols, and so on, which strongly depend on the electrocatalysts employed and the applied electrode potentials. Although high performance liquid chromatography (HPLC), ion chromatography (IC) and nuclear magnetic resonance (NMR) have been employed to analyze the liquid products ${ }^{11,13-15}$, it remains quite challenging and time-consuming to quantify the various liquid products in order to determine the overall FE and assess the activity of the catalysts. A chemical oxygen demand (COD) method is commonly used in environmental analysis, and is based upon the complete oxidation of all organic species to $\mathrm{CO}_{2}$, which is exactly the reverse of the $\mathrm{CO}_{2}$ reduction process ${ }^{16,17}$. In this study, for the first time we propose and employ the COD analysis to determine the overall FE associated with the conversion of $\mathrm{CO}_{2}$ to liquid chemicals and fuels.

Graphene nanosheets have been widely doped and/or modified for catalytic and energy conversion applications ${ }^{18-22}$. The unique electronic and physical properties of graphene may augment the reduction kinetics of $\mathrm{CO}_{2}$, and enhance the reaction kinetics of noble metal nanoparticles ${ }^{23,24}$. Copper is considered to be one of the eminent catalysts for the electrochemical reduction of $\mathrm{CO}_{2}$ to low-carbon fuels for high-density renewable energy storage $\mathrm{e}^{7,8,11,25}$. 

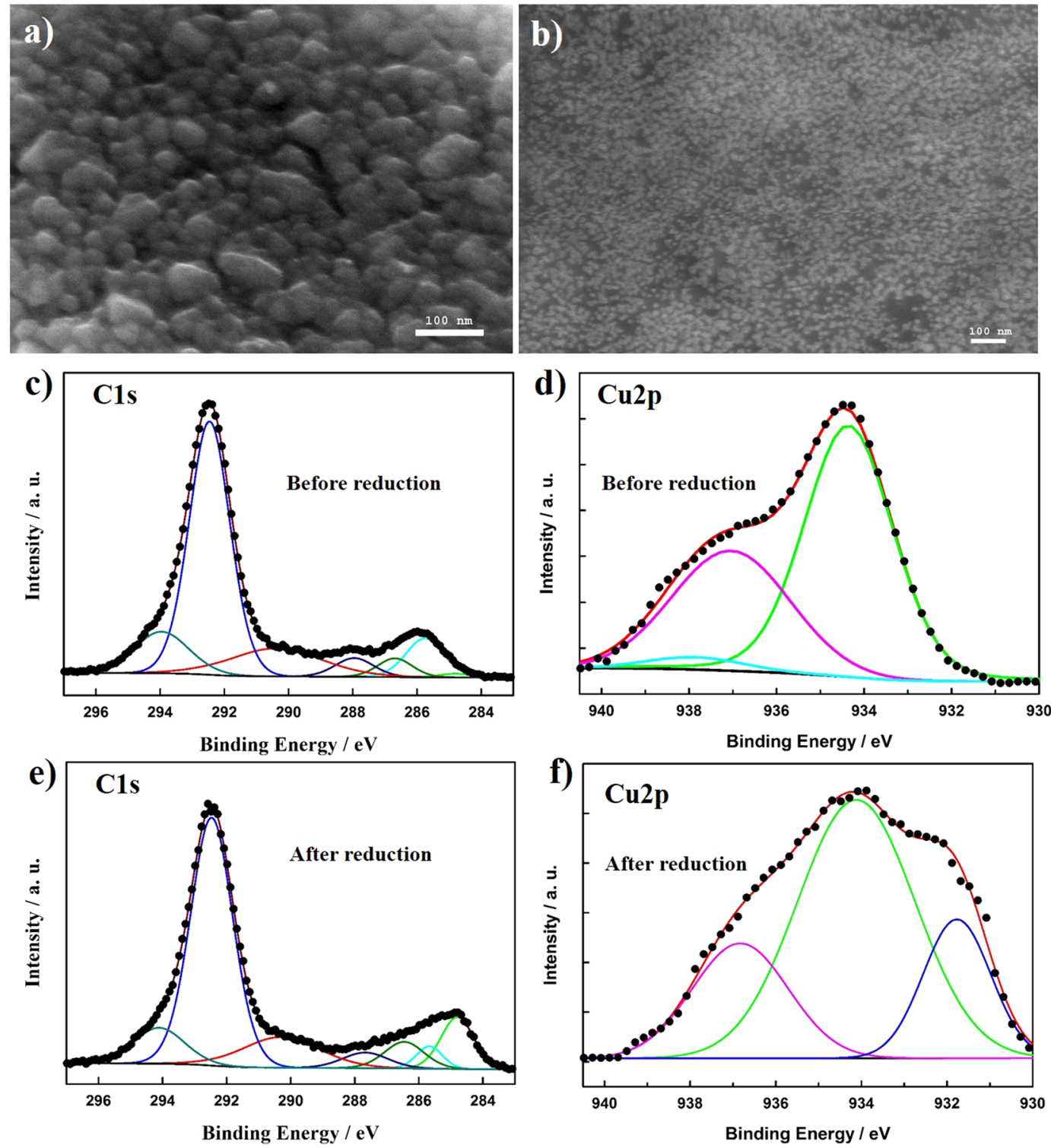

Figure 1. SEM images of the formed $\mathrm{Cu}$ NPs (a) and the Cu-rGO nanocomposite (b) on a Cu substrate. Highresolution XPS spectra of the $\mathrm{C} 1$ s region ( $\mathbf{c}$ and $\mathbf{e}$ ) and the $\mathrm{Cu} 2 \mathrm{p}$ region ( $\mathbf{d}$ and $\mathbf{f}$ ) of the $\mathrm{CuSO}_{4}-\mathrm{GO}$ thin film before the electrochemical treatment and the formed $\mathrm{Cu}-\mathrm{rGO}$ nanocomposite.

It has been reported that $\mathrm{CO}, \mathrm{CH}_{4}, \mathrm{C} 2$ hydrocarbon, alcohols, formate, and acetate could be formed when $\mathrm{Cu}$ was used as an electrode in an aqueous solution ${ }^{11,12,25-27}$. Several studies have been reported wherein the selectivity of $\mathrm{Cu}$ catalysts for the reduction of $\mathrm{CO}_{2}$ was specifically dependent on its crystal facets ${ }^{7,28,29}$. The surface structures of $\mathrm{Cu}$ electrodes, in conjunction with the applied electrode potential, are of intense interest for product selectivity ${ }^{30-33}$. Density Function Theory studies have indicated that defective graphene-supported Cu nanoparticles may modify the structural and electronic properties of copper, toward enhancing the electrochemical reduction of $\mathrm{CO}_{2}$ to fuels (e.g., $\mathrm{CH}_{4}, \mathrm{CO}$, and $\left.\mathrm{HCOOH}\right)^{23,24,34-38}$. However, despite the high catalytic activity of such $\mathrm{Cu}$ catalysts, they still suffer from low stability and large reaction overpotentials. Herein we report on the high-performance $\mathrm{CO}_{2}$ reduction that is enabled by a unique nanocomposite of $\mathrm{Cu}$ NPs and rGO supported on a $\mathrm{Cu}$ substrate with high $\mathrm{FE}$ and stability for the efficient conversion of $\mathrm{CO}_{2}$ to valuable fuels, including $\mathrm{CO}, \mathrm{CH}_{4}$, and formate.

\section{Results}

Syntheses and characterization of CU-rGO nanocomposites. The Cu-rGO nanocomposite was formed directly on a $\mathrm{Cu}$ substrate using a facile electrochemical reduction method. A mixture of GO and $\mathrm{Cu}^{2+}$ precursors was cast on an etched $\mathrm{Cu}$ substrate; and the simultaneous formation of $\mathrm{Cu}$-rGO nanocomposite was achieved via cyclic voltammetry $(\mathrm{CV})$, which was carried out in $0.1 \mathrm{M} \mathrm{Na}_{2} \mathrm{SO}_{4}$ in the potential range from 0.62 to $-0.58 \mathrm{~V}$ vs. RHE for five cycles. The composition and thickness of the formed $\mathrm{Cu}-\mathrm{rGO}$ nanocomposite were also optimized, with the experimental details described in the Methods. Figure 1a and b display the scanning electron 

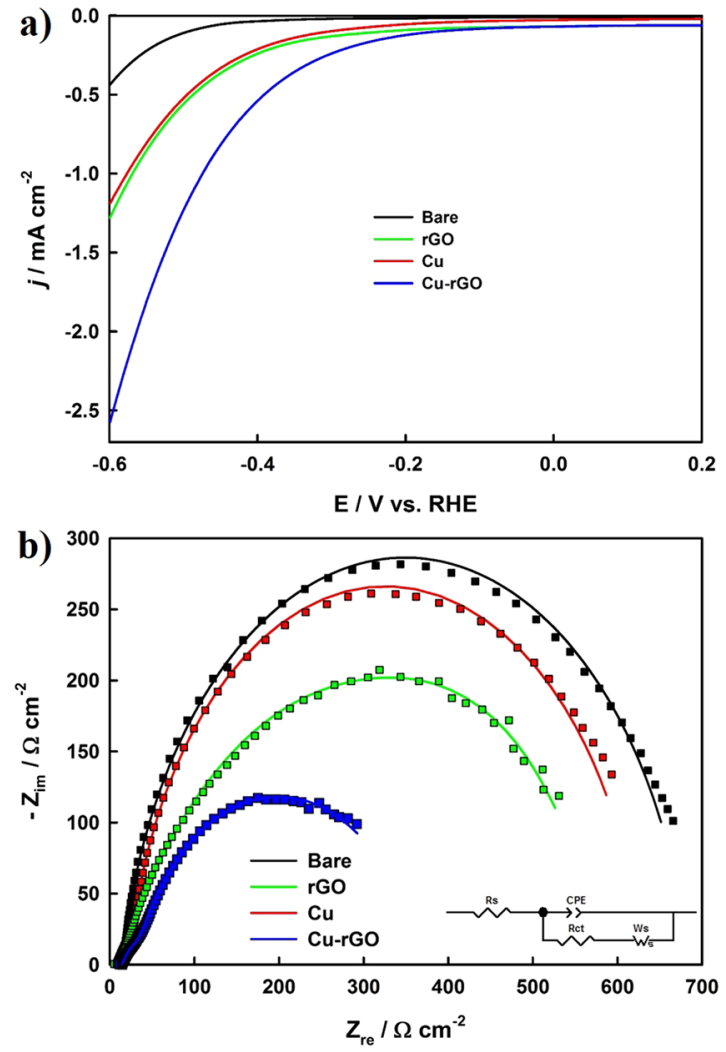

Figure 2. (a) LSV curves of the bare $\mathrm{Cu}$ substrate, $\mathrm{rGO}, \mathrm{Cu}$ NPs and $\mathrm{Cu}-\mathrm{rGO}$ nanocomposite electrodes; and (b) the corresponding Nyquist plots measured at the potential of $-0.4 \mathrm{~V}$ in a $\mathrm{CO}_{2}$-saturated $0.1 \mathrm{M} \mathrm{NaHCO}_{3}$ solution. Inset: the equivalent electric circuit used for fitting the EIS data, where Rs = solution resistance; $\mathrm{CPE}=$ constant phase element; $\mathrm{Rct}=$ charge-transfer resistance; Ws $=$ Warburg impedance (short).

microscope (SEM) images of the formed $\mathrm{Cu}$ NPs in the absence of GO, and the Cu-rGO nanocomposite, respectively. It is evident that large grain-sized $\mathrm{Cu}$ particles were formed in the absence of GO. In contrast, $\mathrm{Cu}$ NPs with an average diameter of $\sim 10 \mathrm{~nm}$ were distributed homogeneously on the rGO. Energy dispersive X-ray spectra (Supplementary Fig. S1) exhibited a strong $\mathrm{Cu}$ peak for the $\mathrm{Cu}$ NPs (Curve i) and an additional strong $\mathrm{C}$ peak for the $\mathrm{Cu}-\mathrm{rGO}$ nanocomposite electrode (Curve ii). X-ray photoelectron spectroscopic (XPS) measurements were further carried out for mixture of the $\mathrm{GO}$ and $\mathrm{Cu}$ precursor mixture as well as for the formed $\mathrm{Cu}-\mathrm{rGO}$ nanocomposite electrode. Figure 1c and e display the high-resolution C1s XPS spectra prior to and following the electrochemical reduction, respectively. A series of fitting peaks were observed at 284.80, 285.76, 286.69, 287.95, and $290.39 \mathrm{eV}$, corresponding to $\mathrm{sp}^{2} \mathrm{C}, \mathrm{C}-\mathrm{OH}, \mathrm{C}-\mathrm{O}, \mathrm{C}=\mathrm{O}$, and $\mathrm{HO}-\mathrm{C}=\mathrm{O}$ bonds, respectively, as observed in $\mathrm{GO}^{21,22}$. The peaks centred at 292.46 and $293.96 \mathrm{eV}$ are due to the $\mathrm{C}-\mathrm{F}_{3}$ and $\mathrm{C}-\mathrm{F}_{2}$ groups of Nafion, which was used as the binding material of the nanocomposite to the substrate. As seen in Table S1, following the electrochemical reduction, the peaks of oxygen-containing groups decreased; and the proportion of $\mathrm{C}=\mathrm{C}$ group increased enormously, revealing that the electrochemical treatment had a significant effect on the diminution of oxygen-containing functional groups. In the case of $\mathrm{Cu}$, prior to the electrochemical treatment, three $\mathrm{Cu} 2 \mathrm{p}$ peaks were observed in Fig. 1d, which might be attributed to the physicochemical interactions of $\mathrm{Cu}(\mathrm{II})$ species with the different functional groups of $\mathrm{GO}^{15,39-41}$. Subsequent to the electrochemical treatment (Fig. 1f), a strong $\mathrm{Cu}(0)$ peak appeared at $934.12 \mathrm{eV}$ and a small $\mathrm{Cu}(\mathrm{I})$ peak was observed at $931.78 \mathrm{eV}$. The associated $\mathrm{Cu} 2 \mathrm{p}$ peak position, assignment, and atomic percentage before and after the electrochemical treatment are listed in Table S2. All the aforementioned results show that the $\mathrm{GO}$ and $\mathrm{Cu}^{2+}$ precursor can be effectively reduced to form the $\mathrm{Cu}$-rGO nanocomposite.

The electrocatalytic activity of the formed $\mathrm{Cu}-\mathrm{rGO}$ nanocomposite was initially studied using linear sweep voltammetry (LSV) and chronoamperometry (CA) in the presence of $\mathrm{CO}_{2}$ in $0.1 \mathrm{M} \mathrm{NaHCO}_{3}(\mathrm{pH} 6.65$ ). Figure $2 \mathrm{a}$ compares the LSV curves of the bare $\mathrm{Cu}$ substrate, $\mathrm{Cu}$ NPs, rGO, and the $\mathrm{Cu}-\mathrm{rGO}$ nanocomposite recorded at $20 \mathrm{mV} \mathrm{s}^{-1}$. The $\mathrm{Cu}-\mathrm{rGO}$ nanocomposite exhibited a much higher current density and earlier onset potential in contrast to the bare $\mathrm{Cu}$ substrate, $\mathrm{Cu}$ NPs, and rGO. The CA curves of these electrodes were measured at $-0.4 \mathrm{~V}$ and compared in Supplementary Fig. S2, showing that the steady-state current was increased in the following order: bare $\mathrm{Cu}<\mathrm{rGO} \approx \mathrm{Cu} \mathrm{NPs}<\mathrm{Cu}-\mathrm{rGO}$. It is noteworthy that the current density of the Cu-rGO nanocomposite was much higher, and the onset potential was much lower in comparison with other copper-based catalysts for the electroreduction of $\mathrm{CO}_{2}$ that have been recently reported in the literature ${ }^{36-38,42-44}$.

Electrochemical impedance spectroscopy (EIS) was employed to determine the charge-transfer resistance. Nyquist plots (Fig. 2b) of the bare $\mathrm{Cu}, \mathrm{Cu}$ NPs, rGO, and Cu-rGO nanocomposite electrodes were recorded in $\mathrm{CO}_{2}$-saturated $0.1 \mathrm{M} \mathrm{NaHCO}_{3}$ aqueous solutions at $-0.4 \mathrm{~V}$. All of the impedance curves exhibited a semi-circle 

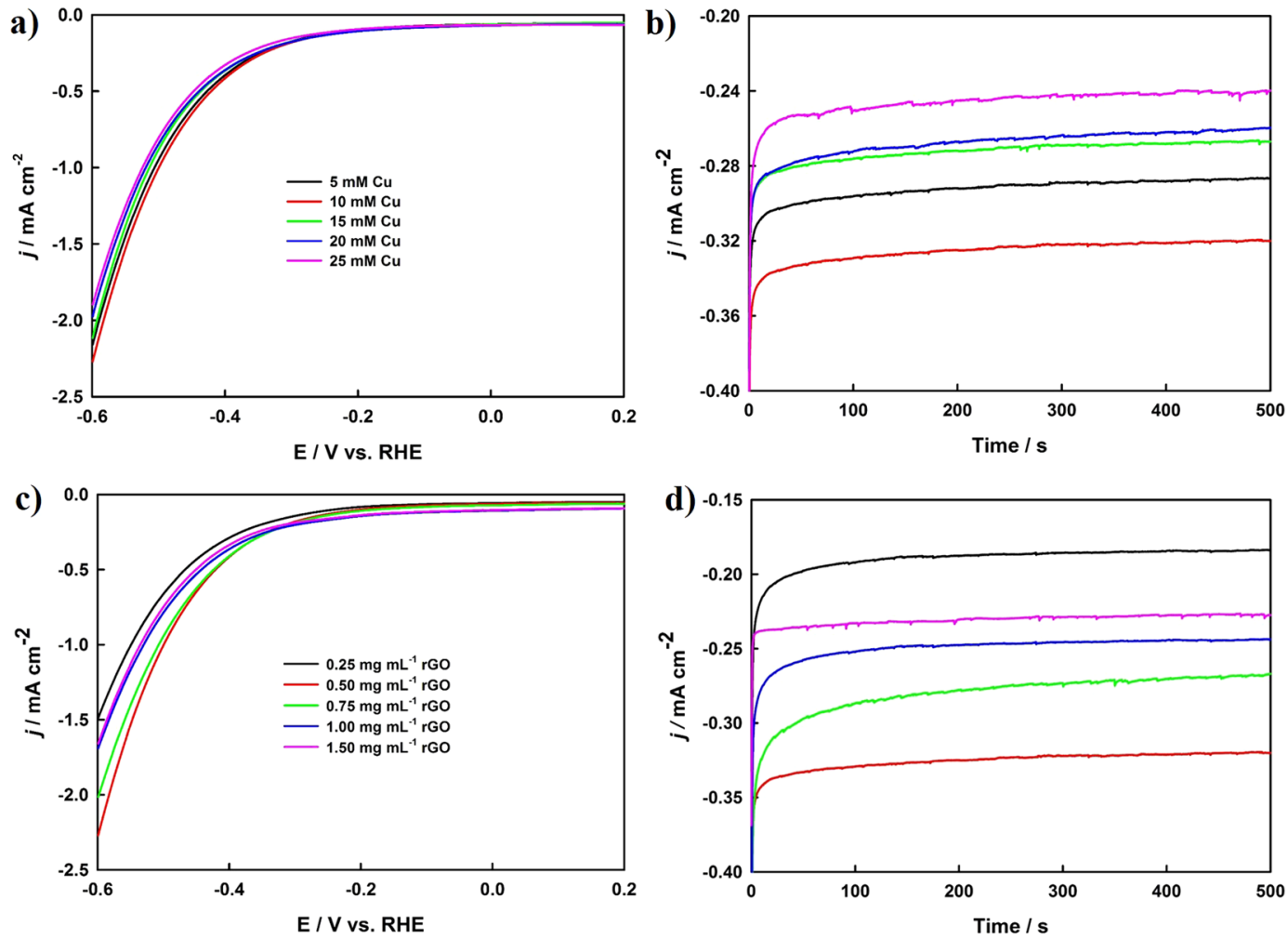

Figure 3. LSV curves (a) and CA plots (b) of the $\mathrm{Cu}-\mathrm{rGO}$ nanocomposite electrodes prepared with a constant GO concentration $\left(0.5 \mathrm{mg} \mathrm{mL}^{-1}\right)$ while the concentration of the $\mathrm{Cu}$ precursor was changed from 5 to $25 \mathrm{mM}$ as listed in Fig. 3a. LSV curves (c) and CA plots (d) for the optimization of the GO concentration while the concentration of the $\mathrm{Cu}$ precursor was maintained at $10 \mathrm{mM}$.

in the low-frequency region, which may correspond to the charge transfer resistance of the $\mathrm{CO}_{2}$ reduction $^{45}$. The equivalent electrical circuit displayed in the inset was employed to fit the experimental data using the Z-view software, and the corresponding fitted results were summarized along with the percentage of errors in Supplementary Table S3. All of the solution resistances (Rs) were small, and the low error percentages indicated that the employed equivalent circuit fitted the impedance data well. All of the CPE-P values were $>0.8$, which signified that the constant phase element (CPE) behaviours were capacitor-like. The $\mathrm{Cu}-\mathrm{rGO}$ nanocomposite exhibited the highest CPE-T value $\left(1817.60 \mu \mathrm{F} \mathrm{cm}^{-2}\right)$, which was over four-fold larger than that of the $\mathrm{Cu} N P s\left(427.38 \mu \mathrm{F} \mathrm{cm}{ }^{-2}\right)$ and over two-fold greater than that of the $\mathrm{rGO}\left(781.40 \mu \mathrm{F} \mathrm{cm}^{-2}\right)$. Moreover, the $\mathrm{Cu}$-rGO nanocomposite exhibited much lower charge-transfer resistance Rct $\left(355.40 \Omega \mathrm{cm}^{-2}\right)$, which was almost half of the Cu NPs $(612.90 \Omega$ $\mathrm{cm}^{-2}$ ). A short Warburg impedance (Ws) associated with Rct was included in the equivalent circuit in order to effectively fit the impedance spectra, indicating that the diffusion resistance also played an important role during the electrochemical reduction of $\mathrm{CO}_{2}$. All of the EIS results further demonstrated that the Cu-rGO nanocomposite exhibited much higher catalytic activity toward the electrochemical reduction of $\mathrm{CO}_{2}$ in comparison to the $\mathrm{Cu}$ NPs and rGO.

In order to optimize the composition and quantity of the nanocomposite, different $\mathrm{Cu}$-rGO nanocomposites were prepared and studied. Figure 3 presents the LSV and CA curves of the prepared Cu-rGO nanocomposites, where the concentration of the $\mathrm{Cu}$ precursor was altered from 5 to $25 \mathrm{mM}$, and the GO concentration was varied from 0.25 to $1.5 \mathrm{mg} \mathrm{mL}^{-1}$. As shown in both LSV (Fig. 3a) and CA (Fig. 3b) plots, the highest current density was achieved with the $10.0 \mathrm{mM} \mathrm{Cu}$ precursor. In the case of GO, the highest activity was observed when $0.5 \mathrm{mg} \mathrm{mL}^{-1}$ GO was used, as seen in Fig. $3 \mathrm{c}$ and d. To study the effects of the thickness of the nanocomposite, similar experiments were conducted with the optimized composite mixture of the $10 \mathrm{mM} \mathrm{Cu}$ precursor and $0.5 \mathrm{mg} \mathrm{mL}^{-1} \mathrm{GO}_{\text {, }}$ where the volume was changed from 25 to $150 \mu \mathrm{L}$. The highest current density was attained with $75 \mu \mathrm{L}$ of the composite mixture, as shown in both the LSV and CA curves (Supplementary Information Fig. S3a and S3b). EIS was further carried out to investigate the charge-transfer resistance of the optimized $\mathrm{Cu}-\mathrm{rGO}$ nanocomposite $(75 \mu \mathrm{L}$ of $10 \mathrm{mM} \mathrm{Cu}$ and $0.5 \mathrm{mg} \mathrm{mL}^{-1} \mathrm{GO}$ mixture) at four different applied electrode potentials (Fig. 4). The EIS curves were effectively fitted with the electrical circuit (inset of Fig. 4) with the results listed in Table S4 (Supplementary Information), revealing that the charge-transfer resistance was significantly decreased from 976.0 to $70.26 \Omega$ $\mathrm{cm}^{-2}$, with the increase of the cathodic potential from -0.3 to $-0.6 \mathrm{~V}$.

Bulk electrolysis of $\mathrm{CO}_{2}$. In an attempt to achieve the bulk electrolysis of $\mathrm{CO}_{2}$, we selected three potentials $(-0.4,-0.5$, and $-0.6 \mathrm{~V})$ for six hours of electrolysis using the optimized Cu-rGO nanocomposite in a $\mathrm{CO}_{2}$-saturated $0.1 \mathrm{M} \mathrm{NaHCO}_{3}$ electrolyte ( $\mathrm{pH}$ 6.65). Figure 5a shows that the current density increased with 


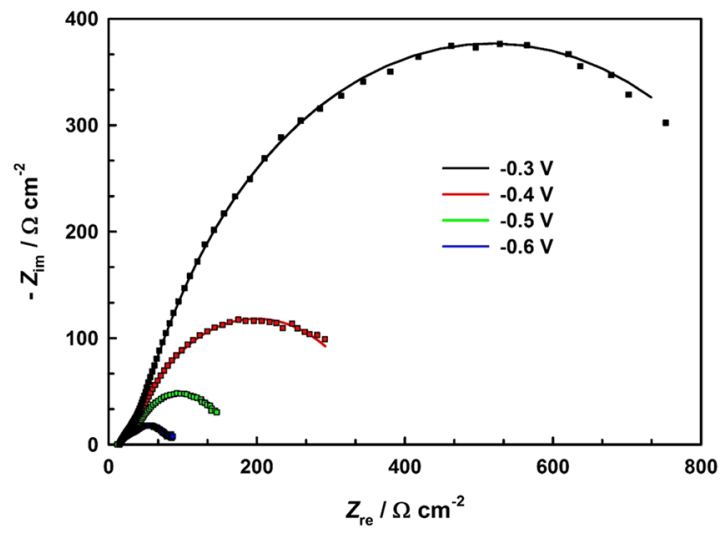

Figure 4. Nyquist plots of the optimized $\mathrm{Cu}-\mathrm{rGO}$ nanocomposite electrode recorded at $-0.3,-0.4,-0.5$, and $-0.6 \mathrm{~V}$ in a $\mathrm{CO}_{2}$ saturated $0.1 \mathrm{M} \mathrm{NaHCO}_{3}$ solution. The symbols denote the experimental data and the solid lines correspond to the fitted results using the equivalent electrical circuit (inset). The amplitude of the modulation potential was $10 \mathrm{mV}$ and the frequency was altered from $100 \mathrm{kHz}$ to $10 \mathrm{mHz}$.

the elevation of the cathode potentials during the bulk electrolysis of $\mathrm{CO}_{2}$, which was indicative of accelerated $\mathrm{CO}_{2}$ reduction reaction rates at more negative potentials. The formation of a large quantity of product was also observed at more negative potentials, revealing that the $\mathrm{Cu}$-rGO nanocomposite facilitated the charge-transfer for the $\mathrm{CO}_{2}$ reduction, while increasing the cathodic potential. Our GC analysis showed that $\mathrm{CO}$ and $\mathrm{CH}_{4}$ were the primary gas products generated from the electrochemical reduction of $\mathrm{CO}_{2}$. To confirm that whether rGO served as the potential carbon source, we have conducted two control experiments: (i) running the CA experiment at $-0.5 \mathrm{~V}$ vs RHE for six hours in an Ar-saturated $0.1 \mathrm{M} \mathrm{NaHCO}_{3}$ solution using the rGO electrode; and (ii) performing the same CA test in an Ar-saturated $0.1 \mathrm{M} \mathrm{Na}_{2} \mathrm{SO}_{4}$ solution using the $\mathrm{Cu}$-rGO nanocomposite. Only hydrogen was detected in the GC analysis for both cases, confirming that the $\mathrm{CO}$ and $\mathrm{CH}_{4}$ products were formed from the electrochemical reduction of $\mathrm{CO}_{2}$ using the $\mathrm{Cu}-\mathrm{rGO}$ nanocomposite as the electrocatalyst. The $\mathrm{FE}$ for the formation of $\mathrm{CO}$ and $\mathrm{CH}_{4}$ at the different applied electrode potentials were calculated and plotted in Fig. 5b, showing that more $\mathrm{CO}$ was generated than $\mathrm{CH}_{4}$ and that the $\mathrm{FE}$ for the formation of the gas products was increased with the raising of the cathodic potential from -0.4 to $-0.6 \mathrm{~V}$.

As mentioned in the introduction, the $\mathrm{COD}$ analysis is just the opposite of the $\mathrm{CO}_{2}$ reduction; and this reverse conversion allows us to rapidly determine the total amount of electrons that are used in the electrochemical reduction of $\mathrm{CO}_{2}$ to produce the various organic liquid fuels as they will be completely oxidized via the following general equation during the COD analysis ${ }^{16,17}$ :

$$
\mathrm{C}_{\mathrm{a}} \mathrm{H}_{\mathrm{b}} \mathrm{O}_{\mathrm{c}}+(\mathrm{a}+\mathrm{b} / 4-\mathrm{c} / 2) \mathrm{O}_{2} \rightarrow \mathrm{a} \mathrm{CO}_{2}+\mathrm{b} / 2 \mathrm{H}_{2} \mathrm{O}
$$

where $\mathrm{a}, \mathrm{b}$, and $\mathrm{c}$ represent the stoichiometric ratio of carbon, hydrogen, and oxygen in the formed organic compounds, respectively. Since each $\mathrm{O}_{2}$ molecule corresponds to a four-electron transfer,

$$
\mathrm{O}_{2}+4 \mathrm{H}^{+}+4 \mathrm{e}^{-} \rightarrow 2 \mathrm{H}_{2} \mathrm{O}
$$

we may use the following equation to calculate the total charge $\left(\mathrm{Q}_{\mathrm{COD}}\right)$, which was consumed for the formation of the liquid fuels during the electrochemical reduction of $\mathrm{CO}_{2}$ :

$$
\mathrm{Q}_{\mathrm{COD}}=\mathrm{COD}\left[\mathrm{mg} \mathrm{L}^{-1} \mathrm{O}_{2}\right] \times(4 F V / 32000)
$$

where $F$ is the Faraday constant and $V$ is the volume of the solution. Thus, the Faradaic efficiency for the formation of the liquid products may be calculated as follows:

$$
\mathrm{FE}_{\mathrm{COD}} \%=\mathrm{Q}_{\mathrm{COD}} / \mathrm{Q} \times 100
$$

where $Q$ is the overall charge passed during the electrochemical reduction of $\mathrm{CO}_{2}$. The $\mathrm{FE}_{\mathrm{COD}}$ at the different potentials was calculated and plotted in Fig. 5b, showing that the FE in the formation of liquid chemicals/fuels was decreased when the cathodic potential was raised from -0.4 to $-0.6 \mathrm{~V}$. Our further HPLC analysis confirmed that the primary liquid product was formate with a trace amount of acetate. For comparison, the CA experiment was also performed at $-0.5 \mathrm{~V}$ in an Ar-saturated $0.1 \mathrm{M} \mathrm{Na}_{2} \mathrm{SO}_{4}$ solution for six hours using the Cu-rGO nanocomposite. The subsequent COD analysis was carried out and no COD change of the solution was observed prior to and after the CA test, further confirming that the increase of the COD value in the electrolysis experiment performed in the $\mathrm{CO}_{2}$-saturated $0.1 \mathrm{M} \mathrm{NaHCO}_{3}$ solution was resulted from the electrochemical reduction of $\mathrm{CO}_{2}$. The total FE of the optimized $\mathrm{Cu}-\mathrm{rGO}$ nanocomposite for the reduction of $\mathrm{CO}_{2}$ included two parts (the formation of the gas and liquid products); and it was calculated to be $76.6 \%, 69.2 \%$, and $74.7 \%$ at the applied electrode potentials of $-0.4,-0.5$, and $-0.6 \mathrm{~V}$ vs. RHE, respectively, and the rest $\sim 25 \%$ might be attributed to the hydrogen evolution. The rates of the formation of the products at the different applied electrode potentials are presented 

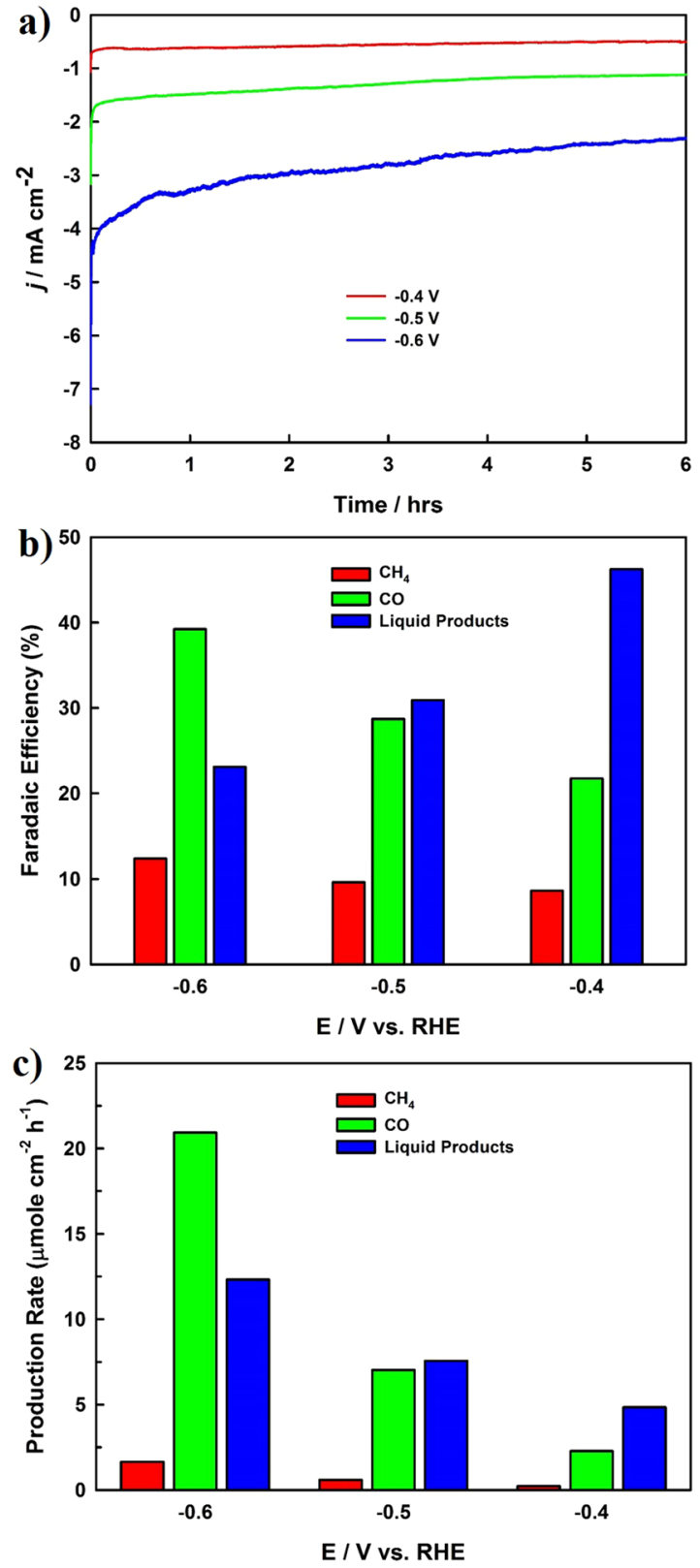

Figure 5. (a) CA curves of the optimized Cu-rGO nanocomposite recorded at the selected potentials of -0.4 , -0.5 , and $-0.6 \mathrm{~V}$ for product analysis. (b) The corresponding Faradaic efficiency of the formed products at the different applied potentials over the six hours. (c) The rates of product formation during the electrochemical reduction of $\mathrm{CO}_{2}$ at the applied potentials on the $\mathrm{Cu}-\mathrm{rGO}$ nanocomposite electrode.

in Fig. $5 c$, revealing that all the production rates were increased with the increase of the cathodic potential from -0.4 to $-0.6 \mathrm{~V}$ and that a significant increase of the $\mathrm{CO}$ formation was observed in comparison of the formation of the other gas and liquid products. Various $\mathrm{Cu}$-based materials have been explored for the electrochemical reduction of $\mathrm{CO}_{2}$, and some of the promising results recently reported in the literature are compared in Table 1, showing that the unique $\mathrm{Cu}-\mathrm{rGO}$ nanocomposite developed in the present study exhibited excellent $\mathrm{FE}$ for the efficient electrocatalytic reduction of $\mathrm{CO}_{2}$ at a relative low overpotential.

Finally, the stability of the optimized $\mathrm{Cu}-\mathrm{rGO}$ nanocomposite was tested at $-0.5 \mathrm{~V}$ in one liter of $\mathrm{CO}_{2}$-saturated $0.1 \mathrm{M} \mathrm{NaHCO}_{3}$ over 15 hours, via the chronoamperometric method (Fig. 6), where $\mathrm{CO}_{2}$ was continuously purged into the solution during the course of the test. Impressively, the current density was almost identical during the entire $\mathrm{CO}_{2}$ reduction electrolyses, which demonstrated the high stability of the $\mathrm{Cu}-\mathrm{rGO}$ nanocomposite electrode. The superior stability was further confirmed by inductively coupled plasma atomic emission spectroscopic (ICP-AES) analysis, where no $\mathrm{Cu}$ was detected in the electrolyte following the electrolysis. 


\begin{tabular}{|c|c|c|c|c|}
\hline Electrocatalyst & \begin{tabular}{|l|} 
Applied \\
potential
\end{tabular} & Products (FE\%) & $\begin{array}{l}\text { Total } \\
\text { FE\% }\end{array}$ & Ref. \\
\hline Oxide derived $\mathrm{Cu}$ & $\begin{array}{l}-0.40 \mathrm{~V} \text { vs. } \\
\text { RHE }\end{array}$ & $\mathrm{CO}(38.5) ; \mathrm{HCOO}^{-}(10.8)$ & 49.3 & 39 \\
\hline Cu nanowire & $\begin{array}{l}-0.795 \mathrm{~V} \text { vs. } \\
\text { RHE }\end{array}$ & $\begin{array}{l}\mathrm{CO}(2.4) ; \mathrm{C}_{2} \mathrm{H}_{4}(7.2) ; \\
\mathrm{C}_{2} \mathrm{H}_{6}(8.3) ; \mathrm{HCOO}^{-}(9.6) ; \\
\mathrm{CH}_{3} \mathrm{CH}_{2} \mathrm{OH}(10.8)\end{array}$ & 38.64 & 46 \\
\hline \multirow[t]{2}{*}{$\begin{array}{l}\text { Carbon nanotube/copper } \\
\text { sheets (CNT/Cu) }\end{array}$} & $\begin{array}{l}-2.8 \mathrm{~V} \text { vs. } \mathrm{Ag} / \\
\mathrm{AgCl}\end{array}$ & $\mathrm{CO}(1.6) ; \mathrm{CH}_{4}(6.8)$ & 7.6 & 43 \\
\hline & $\begin{array}{l}-5.0 \mathrm{~V} \text { vs. } \mathrm{Ag} / \\
\mathrm{AgCl}\end{array}$ & $\begin{array}{l}\mathrm{CO}(5.1) ; \mathrm{CH}_{4}(15.5) ; \mathrm{C}_{2} \mathrm{H}_{4} \\
(1.1)\end{array}$ & 21.7 & \\
\hline $\begin{array}{l}\text { Copper nanoparticles } \\
\text { supported on carbon black } \\
\text { ( } 40 \mathrm{wt} \% \mathrm{Cu} / \mathrm{VC})\end{array}$ & $\begin{array}{l}-1.2 \mathrm{~V} \text { vs. } \mathrm{Ag} / \\
\mathrm{AgCl}\end{array}$ & $\mathrm{CO}(\sim 15.0)$ & 15.0 & 44 \\
\hline $20 \% \mathrm{Cu} / \mathrm{CNT}$ & $-1.7 \mathrm{~V}$ vs. SCE & $\mathrm{CH}_{3} \mathrm{OH}(38.4)$ & 38.4 & 47 \\
\hline $\begin{array}{l}\text { Carbon nanospike electrode } \\
\text { with electronucleated } \mathrm{Cu} \\
\text { nanoparticles (Cu/CNS) }\end{array}$ & $-0.7 \mathrm{~V}$ vs. RHE & $\mathrm{CO}(23.0) ; \mathrm{CH}_{4}(12.0)$ & 25.0 & 36 \\
\hline $\begin{array}{l}\text { Graphene confined Sn } \\
\text { quantum sheets }\end{array}$ & $-1.2 \mathrm{~V}$ vs. SCE & $\mathrm{HCOO}^{-}(30.0)$ & 30.0 & 48 \\
\hline $\begin{array}{l}\text { Cu NPs loaded on glassy } \\
\text { carbon (Cu NP/GC) }\end{array}$ & $-1.3 \mathrm{~V}$ vs. RHE & $\begin{array}{l}\mathrm{CO}(5.5) ; \mathrm{CH}_{4}(40.1) ; \\
\mathrm{C}_{2} \mathrm{H}_{4}(2.3) ; \mathrm{HCOOH}(1.9) ; \\
\mathrm{CH}_{3} \mathrm{COOH}(0.7)\end{array}$ & 50.5 & 35 \\
\hline Oxide derived $\mathrm{Cu}$ foam & $-1.0 \mathrm{~V}$ vs. RHE & $\begin{array}{l}\mathrm{CO}(\sim 5.0) ; \mathrm{HCOO}^{-} \\
(\sim 5.0) ; \mathrm{C}_{2} \mathrm{H}_{4}(\sim 20.0) ; \mathrm{C}_{2} \mathrm{H}_{6} \\
(\sim 25.0)\end{array}$ & 55.0 & 49 \\
\hline $\begin{array}{l}\text { Copper nanoparticles } \\
\text { supported on glassy carbon } \\
(\mathrm{n}-\mathrm{Cu} / \mathrm{C})\end{array}$ & -0.95 vs. RHE & $\mathrm{CH}_{4}(\sim 15.0)$ & 15.0 & 25 \\
\hline Cu mesocrystals & $\begin{array}{l}-0.99 \mathrm{~V} \text { vs. } \\
\text { RHE }\end{array}$ & $\begin{array}{l}\mathrm{CO}(\sim 2.0) ; \mathrm{CH}_{4}(\sim 3.0) ; \\
\mathrm{C}_{2} \mathrm{H}_{4}(\sim 27.0)\end{array}$ & 32.0 & 50 \\
\hline Cu nanoflower & $-1.6 \mathrm{~V}$ vs. RHE & $\begin{array}{l}\mathrm{HCOOH}(\sim 50.0) ; \mathrm{CH}_{4} \\
(\sim 5.0) ; \mathrm{C}_{2} \mathrm{H}_{4}(\sim 10.0)\end{array}$ & 65.0 & 28 \\
\hline Cu-rGO & $\begin{array}{l}-0.4 \mathrm{~V} \text { vs. } \\
\text { RHE (-1.0 V } \\
\text { vs. Ag/AgCl) }\end{array}$ & $\begin{array}{l}\mathrm{CO}(21.7) ; \mathrm{CH}_{4}(8.6) ; \\
\text { Liquid products (46.2) }\end{array}$ & 76.6 & Present work \\
\hline
\end{tabular}

Table 1. Comparison of some promising Cu-based catalysts for the electrochemical reduction of $\mathrm{CO}_{2}$ recently reported in the literature.

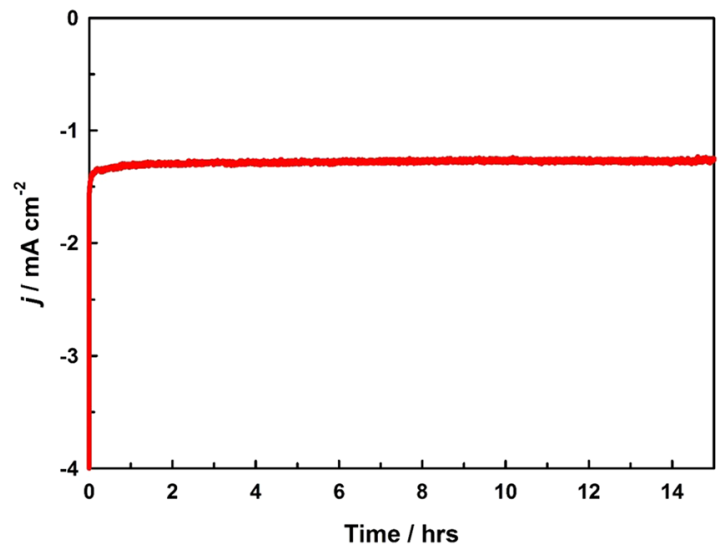

Figure 6. The stability test of the optimized nanocomposite electrode carried at $-0.5 \mathrm{~V}$ in a $\mathrm{CO}_{2}$-saturated $0.1 \mathrm{M} \mathrm{NaHCO}_{3}$ solution under continuous $\mathrm{CO}_{2}$ purging.

\section{Discussion}

A unique $\mathrm{Cu}-\mathrm{rGO}$ nanocomposite has been developed in the present study as a high-performance electrocatalyst for the efficacious reduction of $\mathrm{CO}_{2}$ in an aqueous solution, with a high current density and a low cathodic potential. The superior electrocatalytic activity and stability of the $\mathrm{Cu}-\mathrm{rGO}$ nanocomposite achieved in our study can be attributed to the uniformly distributed small $\mathrm{Cu}$ nanoparticles on the $\mathrm{rGO}$ and the synergistic coupling effect of the formed nanocomposite. The electron transfer between the rGO and $\mathrm{Cu}$ nanoparticles may increase localized electron concentrations, resulting in significant enhancement of the catalytic activities of the nanocomposite for the electrochemical reduction of $\mathrm{CO}_{2}$. The $\mathrm{GC}$ measurements indicated that $\mathrm{CO}$ and $\mathrm{CH}_{4}$ were the primary gas products, while our HPLC analysis revealed that $\mathrm{HCOO}^{-}$was the dominant liquid product. In addition, we 
have employed COD analysis to quantify the overall liquid products, which provides a facile, rapid, and accurate method for the determination of the total $\mathrm{FE}$ for the conversion of $\mathrm{CO}_{2}$ to liquid products. The COD analysis may become a universal approach for quantification of the overall liquid products generated in other $\mathrm{CO}_{2}$ conversion processes, for instance, photochemical and photoelectrochemical reduction of $\mathrm{CO}_{2}$. The easy fabrication, cost-effectiveness, high intrinsic activity, superior stability, and excellent FE make the Cu-rGO nanocomposite developed in this study a very promising catalyst for the efficient electrochemical conversion of $\mathrm{CO}_{2}$ to valuable fuels. This might enable a new strategy for the restoration of the carbon balance, while contributing to the resolution of the climate change.

\section{Methods}

Materials. Graphene oxide, $\mathrm{CuSO}_{4} .5 \mathrm{H}_{2} \mathrm{O}$ (99.999\%), $\mathrm{NaHCO}_{3}(\geq 99.0 \%), \mathrm{Na}_{2} \mathrm{SO}_{4}(\geq 99.5 \%)$ and a 10 wt.\% Nafion solution were obtained from Sigma Aldrich. Copper foil (99.9985\%, $0.5 \mathrm{~mm}$ thick) was purchased from Alfa Aesar; copper wire (99.9\%, $1.0 \mathrm{~mm}$ diameter) was purchased from Sigma Aldrich; and carbon dioxide (99.9\%) was purchased from Praxair. All electrochemical experiments were conducted in a $0.1 \mathrm{M} \mathrm{NaHCO}_{3}$ electrolyte solution under $\mathrm{CO}_{2}$ saturation. Double distilled water treated by a Nanopure Diamond water purification system $(18 \mathrm{M} \Omega \mathrm{cm})$ was used in the preparation of all the solutions. All chemicals were used directly without further treatment.

Synthesis of $\mathrm{Cu}-\mathrm{rGO}$ nanocomposites. To optimize the concentration of $\mathrm{Cu}$ precursor, a $50 \mu \mathrm{L}$ mixed solution of Nafion $(0.5 \%), \mathrm{GO}\left(0.5 \mathrm{mg} \mathrm{mL}^{-1}\right)$ and $\mathrm{CuSO}_{4} .5 \mathrm{H}_{2} \mathrm{O}(5.0,10.0,15.0,20.0$, and $25.0 \mathrm{mM})$ was cast on a $1.0 \mathrm{~cm}^{2} \mathrm{Cu}$ foil, which was etched for $30 \mathrm{~s}$ in $35 \% \mathrm{HNO}_{3}$, washed with deionized water, and dried. To optimize the concentration of GO, a $50 \mu \mathrm{L}$ suspension of Nafion $(0.5 \%), \mathrm{CuSO}_{4} .5 \mathrm{H}_{2} \mathrm{O}(10 \mathrm{mM})$, and $\mathrm{GO}(0.25,0.5,0.75,1.0$ and $1.50 \mathrm{mg} \mathrm{mL}^{-1}$ ) was cast onto the etched $1.0 \mathrm{~cm}^{2} \mathrm{Cu}$ foil. Similarly, to optimize the Cu-rGO thickness, altered volumes of the suspension solution $(25,50,75,100$ and $150 \mu \mathrm{L})$ containing $10.0 \mathrm{mM} \mathrm{CuSO}_{4} \cdot 5 \mathrm{H}_{2} \mathrm{O}, 0.5 \%$ Nafion, and a $0.5 \mathrm{mg} \mathrm{mL}^{-1} \mathrm{GO}$ were cast on the etched $1.0 \mathrm{~cm}^{2} \mathrm{Cu}$ substrate.

The simultaneous formation of the $\mathrm{Cu}$-rGO nanocomposite was carried out in $0.1 \mathrm{M} \mathrm{Na}_{2} \mathrm{SO}_{4}$ via cyclic voltammetry in the potential range between 0.0 to $-1.2 \mathrm{~V}$ (vs. $\mathrm{Ag} / \mathrm{AgCl}$ ) for five cycles. The prepared $\mathrm{Cu}-\mathrm{rGO}$ nanocomposites were subsequently rinsed with a copious volume of water and employed for further surface characterization and electrochemical measurements.

For comparison, $\mathrm{Cu}$ nanoparticles (NPs) were prepared using the same electrochemical reduction approach in the absence of GO. Briefly, a mixture of $\mathrm{CuSO}_{4} .5 \mathrm{H}_{2} \mathrm{O}(10.0 \mathrm{mM})$ and Nafion $(0.5 \%)$ in water was prepared and sonicated for 20 minutes. Subsequently, $75 \mu \mathrm{L}$ of the mixture was cast on the etched $\mathrm{Cu}$ foil surface and dried in ambient air at room temperature. The rGO sheet electrode was then prepared by applying the identical conditions mentioned above for the $\mathrm{Cu}$ NPs; however, only GO $\left(0.5 \mathrm{mg} \mathrm{mL}^{-1}\right)$ with Nafion was used.

Structural characterization. Morphological surface studies and EDX analysis were carried out using a FE-SEM (Hitachi SU-70). XPS spectra were recorded via a Thermo Fisher XPS system, where the size of the $\mathrm{X}$-ray spot was $400 \mathrm{~mm}$, with an $\mathrm{Al} \mathrm{K \alpha}$ monochromatic source. XPSPEAK 4.1 software was used for all of the data processing.

Electrochemical characterization. Linear Sweep Voltammetry and chronoamperometry were carried out with a CHI660E electrochemical workstation (CH Instrument Inc. USA) utilizing a conventional one-compartment three-electrode cell, whereas a platinum coil $\left(10 \mathrm{~cm}^{2}\right)$ was used as the counter electrode. A silver/silver chloride electrode $(\mathrm{Ag} / \mathrm{AgCl}, 3.0 \mathrm{M})$ was utilized as the reference electrode and all the aforementioned electrode potentials were converted to the reversible hydrogen electrode (RHE) scale using the following equation:

$$
\mathrm{E}(\mathrm{vs} . \mathrm{RHE})=\mathrm{E}(\mathrm{vs} . \mathrm{Ag} / \mathrm{AgCl})+0.210 \mathrm{~V}+0.0591 \mathrm{~V} \times \mathrm{pH}
$$

A VoltaLab potentiostat (PGZ-301) was employed for the Electrochemical Impedance Spectroscopic (EIS) measurements, and the frequency was varied from $100 \mathrm{kHz}$ to $10 \mathrm{mHz}$ with an a.c. voltage amplitude of $10 \mathrm{mV}$. Data acquisition and analyses were performed using Z-view software, which was employed to fit and obtain an equivalent circuit for EIS data. The solution was purged with $\mathrm{CO}_{2}$ in order to achieve a $\mathrm{CO}_{2}$-saturated condition. All electrochemical experiments were conducted at ambient room temperature $\left(20 \pm 2{ }^{\circ} \mathrm{C}\right)$.

Product analysis. A gas-tight two-compartment electrochemical cell was used for the product formation and analysis. A cationic exchange membrane (CMI-7000S) was utilized as a separator in the cell. Each compartment contained $35.0 \mathrm{ml}$ of the electrolyte; the working electrode and reference electrode $(\mathrm{Ag} / \mathrm{AgCl})$ were in the same compartment, whereas the counter electrode was in a separate compartment. Prior to testing, the electrolyte was purged once again with $\mathrm{CO}_{2}$ gas for at least 30 minutes. A gas-tight syringe (Hamilton $\left.{ }^{\mathrm{TM}}, 50 \mu \mathrm{L}\right)$ was used to transfer the evolved gases into the gas chromatography (Varian 450-GC) to analyze the gas products. The resulting liquid products were qualitatively analyzed using HPLC (Varian Prostar 230 with a Symmetry ${ }^{\circledR} \mathrm{C} 8$ column containing dimethyloctylsilyl bonded amorphous silica-acetonitrile). The COD analysis was conducted using 174-334 accu-TEST standard range (5-150 mg/l) twist cap vials for quantitative determination. The solution $(2.0 \mathrm{~mL})$ was then transferred to a vial that contained a chromic acid solution, heated to $150^{\circ} \mathrm{C}$ for two hours and then allowed to cool. To establish the actual COD values, the results were subtracted from the values of a blank solution $\left(\mathrm{CO}_{2}\right.$ saturated $0.1 \mathrm{M} \mathrm{NaHCO}_{3}$ solution). The $\mathrm{UV}$ absorbance was recorded at $420 \mathrm{~nm}$ using an HACH-DR 2800 portable spectrophotometer. 


\section{References}

1. Gao, S. et al. Partially oxidized atomic cobalt layers for carbon dioxide electroreduction to liquid fuel. Nature 529, 68-71 (2016).

2. Wu, J. et al. A metal-free electrocatalyst for carbon dioxide reduction to multi-carbon hydrocarbons and oxygenates. Nature Commun. 7, 13869 (2016).

3. Liu, M. et al. Enhanced electrocatalytic $\mathrm{CO}_{2}$ reduction via field-induced reagent concentration. Nature 537, 382-386 (2016).

4. Asadi, M. et al. Nanostructured transition metal dichalcogenide electrocatalysts for $\mathrm{CO}_{2}$ reduction in ionic liquid. Science 353, 467-470 (2016).

5. Zahran, Z. N., Mohamed, E. A. \& Naruta, Y. Bio-inspired cofacial Fe porphyrin dimers for efficient electrocatalytic $\mathrm{CO}_{2}$ to $\mathrm{CO}$ conversion: Overpotential tuning by substituents at the porphyrin rings. Sci. Rep. 6, 24533 (2016).

6. Hori, Y. In Modern Aspects of Electrochemistry, Vol. 42 (Eds: C. G. Vayenas, R. E. White, M. E. Gamboa-Aldeco), Springer, New York, 89-189 (2008).

7. Peterson, A. A., Pedersen, F. A., Studt, F., Rossmeisl, J. \& Nørskov, J. K. How copper catalyzes the electroreduction of carbon dioxide into hydrocarbon fuels. Energ. Environ. Sci. 3, 1311-1315 (2010)

8. Peterson, A. A. \& Nørskov, J. K. Activity descriptors for $\mathrm{CO}_{2}$ electroreduction to methane on transition-metal catalysts. J. Phys. Chem. Lett. 3, 251-258 (2012).

9. Zhang, J. et al. In situ formation of oxygen vacancy in perovskite $\mathrm{Sr}_{0.95} \mathrm{Ti}_{0.8} \mathrm{Nb}_{0.1} \mathrm{M}_{0.1} \mathrm{O}_{3}(\mathrm{M}=\mathrm{Mn}$, Cr) toward efficient carbon dioxide electrolysis. Sci. Rep. 4, 7082 (2014).

10. Jin, F. et al. Highly efficient and autocatalytic $\mathrm{H}_{2} \mathrm{O}$ dissociation for $\mathrm{CO}_{2}$ reduction into formic acid with zinc. Sci. Rep. 4, 4503 (2014).

11. Li, C. W., Ciston, J. \& Kanan, M. W. Electroreduction of carbon monoxide to liquid fuel on oxide-derived nanocrystalline copper. Nature 508, 504-507 (2014).

12. Wang, X. Y. et al. Fixation of $\mathrm{CO}_{2}$ by electrocatalytic reduction to synthesis of dimethyl carbonate in ionic liquid using effective silver-coated nanoporous copper composites. Chin. Chem. Lett. 21, 987-990 (2010).

13. Sun, L., Ramesha, G. K., Kamat, P. V. \& Brennecke, J. F. Switching the reaction course of electrochemical $\mathrm{CO}_{2}$ reduction with ionic liquids. Langmuir 30, 6302-6308 (2014).

14. Lee, S. et al. Sustainable production of formic acid by electrolytic reduction of gaseous carbon dioxide. J. Mater. Chem. A. 3, 3029-3034 (2015).

15. Grace, A. N. et al. Electrochemical reduction of carbon dioxide at low overpotential on a polyaniline/Cu $\mathrm{O}_{2}$ nanocomposite based electrode. Appl. Energ. 120, 85-94 (2014).

16. Zhang, Z., Chang, X. \& Chen, A. Determination of chemical oxygen demand based onphotoelectrocatalysis of nanoporous TiO 2 electrodes. Sens. Actuators B 223, 664-670 (2016).

17. Qu, X., Tian, M., Chen, S., Liao, B. \& Chen, A. Determination of chemical oxygen demand based on novel photoelectro-bifunctional electrodes. Electroanalysis 23, 1267-1275 (2011).

18. Kamat, P. V. Graphene-based nanoassemblies for energy conversion. J. Phys. Chem. Lett. 2, 242-251 (2011).

19. Qu, L., Liu, Y., Baek, J.-B. \& Dai, L. Nitrogen-doped graphene as efficient metal-free electrocatalyst for oxygen reduction in fuel cells. ACS Nano 4, 1321-1326 (2010).

20. Kamat, P. V. Graphene-based nanoarchitectures. Anchoring semiconductor and metal nanoparticles on a two-dimensional carbon support. J. Phys. Chem. Lett. 1, 520-527 (2010).

21. Govindhan, M. \& Chen, A. Simultaneous synthesis of gold nanoparticle/graphene nanocomposite for enhanced oxygen reduction reaction. J. Power Sources 274, 928-936 (2015).

22. Govindhan, M., Mao, B. \& Chen, A. Novel cobalt quantum dot/graphene nanocomposites as highly efficient electrocatalysts for water splitting. Nanoscale 8, 1485-1492 (2016).

23. Lim, D.-H. et al. Carbon dioxide conversion into hydrocarbon fuels on defective graphene-supported Cu nanoparticles from first principles. Nanoscale 6, 5087-5092 (2014).

24. Tripkovic, V. et al. Electrochemical $\mathrm{CO}_{2}$ and $\mathrm{CO}$ reduction on metal-functionalized porphyrin-like graphene. J. Phys. Chem. C 117, 9187-9195 (2013).

25. Manthiram, K., Beberwyck, B. J. \& Alivisatos, A. P. Enhanced electrochemical methanation of carbon dioxide with a dispersible nanoscale copper catalyst. J. Am. Chem. Soc. 136, 13319-13325 (2014).

26. Noda, H. et al. Electrochemical reduction of carbon dioxide at various metal electrodes in aqueous potassium hydrogen carbonate solution. Bull. Chem. Soc. Jpn. 63, 2459-2462 (1990).

27. Shibata, H., Moulijn, J. A. \& Mul, G. Enabling electrocatalytic fischer-tropsch synthesis from carbon dioxide over copper-based electrodes. Catal. Lett. 123, 186-192 (2008).

28. Xie, J.-F. et al. Efficient electrochemical $\mathrm{CO}_{2}$ reduction on a unique chrysanthemum-like Cu nanoflower electrode and direct observation of carbon deposite. Electrochim. Acta 139, 137-144 (2014).

29. Schouten, K. J. P., Qin, Z., Gallent, E. P. \& Koper, M. T. M. Two pathways for the formation of ethylene in CO reduction on singlecrystal copper electrodes. J. Am. Chem. Soc. 134, 9864-9867 (2012).

30. Reske, R. et al. Controlling catalytic selectivities during $\mathrm{CO}_{2}$ electroreduction on thin $\mathrm{Cu}$ metal overlayers. J. Phys. Chem. Lett. 4, 2410-2413 (2013).

31. Goncalves, M. R. et al. Electrochemical conversion of $\mathrm{CO}_{2}$ to $\mathrm{C} 2$ hydrocarbons using different ex situ copper electrodeposits. Electrochim. Acta 102, 388-392 (2013).

32. Kauffman, D. R., Ohodnicki, P. R., Kail, B. W. \& Matranga, C. Selective electrocatalytic activity of ligand stabilized copper oxide nanoparticles. J. Phys. Chem. Lett. 2, 2038-2043 (2011).

33. Tang, W. et al. The importance of surface morphology in controlling the selectivity of polycrystalline copper for $\mathrm{CO}_{2}$ electroreduction. Phys. Chem. Chem. Phys. 14, 76-81 (2012).

34. Li, Y., Su, H., Chan, S. H. \& Sun, Q. $\mathrm{CO}_{2}$ electroreduction performance of transition metal dimers supported on graphene: a theoretical study. ACS Catal 5, 6658-6664 (2015).

35. Lum, Y. et al. Trace levels of copper in carbon materials show significant electrochemical $\mathrm{CO}_{2}$ reduction activity. ACS Catal. 6 , 202-209 (2016).

36. Song, Y. et al. High-selectivity electrochemical conversion of $\mathrm{CO}_{2}$ to ethanol using a copper nanoparticle/N-doped graphene electrode. Chemistry Select 1, 1-8 (2016).

37. Alves, D. C. B., Silva, R., Voiry, D., Asefa, T. \& Chhowalla, M. Copper nanoparticles stabilized by reduced graphene oxide for $\mathrm{CO}_{2}$ reduction reaction. Mat. Ren. Sust. Energ. 4, 2 (2015).

38. Liu, X., Zhu, L., Wang, H., He, G. \& Bian, Z. Catalysis performance comparison for electrochemical reduction of $\mathrm{CO}_{2}$ on $\mathrm{Pd}_{-\mathrm{Cu} /}$ graphene catalyst. RSC Adv. 6, 38380-38387 (2016).

39. $\mathrm{Li}, \mathrm{C}$. W. \& Kanan, M. W. $\mathrm{CO}_{2}$ reduction at low overpotential on $\mathrm{Cu}$ electrodes resulting from the reduction of thick $\mathrm{Cu}_{2} \mathrm{O}$ films. J. Am. Chem. Soc. 134, 7231-7234 (2012).

40. Kim, D., Resasco, J., Yu, Y., Asiri, A. M. \& Yang, P. Synergistic geometric and electronic effects for electrochemical reduction of carbon dioxide using gold-copper bimetallic nanoparticles. Nat. Commun. 5, 4948 (2014).

41. Yan, K. \& Chen, A. Selective hydrogenation of furfural and levulinic acid to biofuels on the ecofriendly Cu-Fe catalyst. Fuel $\mathbf{1 1 5}$, 101-108 (2014).

42. Jia, F., Yu, X. \& Zhang, L. Enhanced selectivity for the electrochemical reduction of $\mathrm{CO}_{2}$ to alcohols in aqueous solution with nanostructured $\mathrm{Cu}-\mathrm{Au}$ alloy as catalyst. J. Power Sources 252, 85-89 (2014). 
43. Koo, Y. et al. Aligned carbon nanotube/copper sheets: a new electrocatalyst for $\mathrm{CO}_{2}$ reduction to hydrocarbons. RSC Adv. 4, 16362-16367 (2014).

44. Baturina, O. A. et al. $\mathrm{CO}_{2}$ electroreduction to hydrocarbons on carbon-supported Cu nanoparticles. ACS Catal. 4, 3682-3695 (2014).

45. Koleli, F., Ropke, T. \& Hamann, C. H. Electrochemical impedance spectroscopic investigation of $\mathrm{CO} 2$ reduction on polyaniline in methanol. Electrochim. Acta 48, 1595-1601 (2003).

46. Raciti, D., Livi, K. J. \& Wang, C. Highly dense Cu nanowires for low-overpotential $\mathrm{CO}_{2}$ reduction. Nano Lett. 15, 6829-6835 (2015).

47. Hossain, S. S., Rahman, S. \& Ahmed, S. Electrochemical reduction of carbon dioxide over CNT-supported nanoscale copper electrocatalysts. J. Nanomater. 2014, 374318 (2014)

48. Lei, F. et al. Metallic tin quantum sheets confined in graphene toward high-efficiency carbon dioxide electroreduction. Nat. Commun. 7, 12697 (2016).

49. Dutta, A., Rahaman, M., Luedi, N. C., Mohos, M. \& Broekmann, P. Morphology matters: tuning the product distribution of $\mathrm{CO}_{2}$ electroreduction on oxide-derived Cu foam catalysts. ACS Catal. 6, 3804-3814 (2016).

50. Chen, C. S. et al. Stable and selective electrochemical reduction of carbon dioxide to ethylene on copper mesocrystals. Catal. Sci. Technol. 5, 161-168 (2015).

\section{Acknowledgements}

This work was supported by a Discovery Grant from the Natural Sciences and Engineering Research Council of Canada (NSERC RGPIN-2015-06248). M. N. Hossain acknowledges the Ontario Trillium Scholarship. A. Chen acknowledges NSERC and the Canada Foundation of Innovation (CFI) for the Canada Research Chair Award in Materials and Environmental Chemistry.

\section{Author Contributions}

A.C. and M.N.H. developed the concept and designed the experiments. M.N.H. prepared and characterized all electrodes and performed all electrochemical experiments. J.W. performed G.C., H.P.L.C., and ICP-AES analysis. All the authors compiled and contributed to the overall scientific interpretation and editing of the manuscript.

\section{Additional Information \\ Supplementary information accompanies this paper at doi:10.1038/s41598-017-03601-3}

Competing Interests: The authors declare that they have no competing interests.

Publisher's note: Springer Nature remains neutral with regard to jurisdictional claims in published maps and institutional affiliations.

(c) (i) Open Access This article is licensed under a Creative Commons Attribution 4.0 International License, which permits use, sharing, adaptation, distribution and reproduction in any medium or format, as long as you give appropriate credit to the original author(s) and the source, provide a link to the Creative Commons license, and indicate if changes were made. The images or other third party material in this article are included in the article's Creative Commons license, unless indicated otherwise in a credit line to the material. If material is not included in the article's Creative Commons license and your intended use is not permitted by statutory regulation or exceeds the permitted use, you will need to obtain permission directly from the copyright holder. To view a copy of this license, visit http://creativecommons.org/licenses/by/4.0/.

(c) The Author(s) 2017 